\title{
Flame Retardant and Mechanical Properties of Modified Paper Using Inorganic Salts for Packaging Applications
}

\author{
Ahmed M. Youssef ${ }^{1{ }^{*},}$, Ola A. Mohamed ${ }^{2}$, M. El-Samahy ${ }^{1}$, Amal H. Abd-El Kader ${ }^{3}$ and \\ Luhac Pichtec ${ }^{4}$ \\ ${ }^{1}$ Packing \& Packaging Materials Department, National Research Center, Dokki, Cairo, Egypt \\ ${ }^{2}$ Tanning \& Leather Technology Department, National Research Center, Cairo, Egypt \\ ${ }^{3}$ Paper and Cellulose Department, National Research Center, Cairo, Egypt; Taif University, Chemistry \\ Department, KSA \\ ${ }^{4}$ Polymer Department, Science Technology, Gdansk, Poland
}

\begin{abstract}
The paper sheet prepared from unbleached rice straw containing different concentration of inorganic salts, that work as flame retardant additives (Lithium hydroxide one hydrate $\left(\mathrm{LiOH} .1 \mathrm{H}_{2} \mathrm{O}\right)$, Magnesium hydroxide $\left(\mathrm{Mg}(\mathrm{OH})_{2}\right.$. $\left.15 \mathrm{H}_{2} \mathrm{O}\right)$, aluminum sulphate $\left(\mathrm{Al}_{2}\left(\mathrm{SO}_{4}\right)_{3}\right)$ and calcium carbonate $\left(\mathrm{CaCO}_{3}\right)$ ) were investigated using horizontal burning test against flame retardant. Also, the prepared paper sheets were characterized using scanning electron microscope (SEM), thermal gravimetric analysis (TGA) and Infrared spectroscopy (IR). Furthermore, the water absorption was determined. In addition, the mechanical properties (breaking length, tear factor and burst factor) of the prepared paper sheet were evaluated. Correspondingly, the physical (structure and mechanical) properties of the prepared paper sheet were enhanced in terms of tensile, tear factor and water absorption. Also, delaying firing process will help in protecting the materials from burning, saving many of economic effect. So the prepared paper sheet can be used for different industrial applications especially in packaging applications.
\end{abstract}

Keywords: Flame retardant, unbleached rice straw, paper sheet, packaging, SEM, TGA.

\section{INTRODUCTION}

Fire safety is an all-encompassing need in modern society as the damage caused by fire results in significant loss. Paper and polymer make up a large amount of materials used in everyday life, in many cases these materials contribute significantly to fires when ignition sources are present. Paper plays an important role in people's lives and social development, and it has a wide range of applications [1-4]. However, typical paper and paper products are highly flammable. The burning of paper and paper products can contribute greatly to the seriousness of fires, so there is a strong motivation for development of flame retardant treatments for paper $[5,6]$.

It is well known that the poor thermal stability of paper, which has an ignition temperature of approximately $232^{\circ} \mathrm{C}$, can easily ignite from open flames [7]. This can be attributed to chemical composition of plant fibers, which are complex materials. It composed of an orderly arrangement of cells within a cell wall including varying amounts of cellulose, hemicellulose, lignin and extractives [8-10], this easy degradation of celluloses and hemicelluloses of fibers help in weak thermal

*Address correspondence to this author at the Packaging and Packing Materials Department, National Research Center, Dokki, Cairo, Egypt; Tel: (202) 33322418; Fax: (202) 33370931; E-mail: amyoussef27@yahoo.com; drahmadyoussef@hotmail.com stability $[11,12]$. However, in practical applications, the suitability of certain paper grades to high temperature conditions is sometimes needed. For example, hot sheets of steel (at the temperature from $190^{\circ} \mathrm{C}$ to $200^{\circ} \mathrm{C}$ ) are separated by interleaving paper during the production process of stainless steel, and the pattern on leather release paper is transferred to artificial or synthetic leather at temperature from $160^{\circ} \mathrm{C}$ to $200^{\circ} \mathrm{C}$, so the thermal stability of the paper at $200^{\circ} \mathrm{C}$ is very important parameter [13, 14].

Flame retardant papers on the market basically belong to 4 categories: chlorine- type flame retardantbased, bromine-type flame retardant-based [15], phosphorus and flame retardant-based [16], inorganic flame retardant and natural fibers, where the former is the main ingredient. The inorganic based ones. Using inorganic salts such as Aluminum sulfate, Magnesium hydroxide, Lithium hydroxide and Calcium carbonate is preferred as an alternative to the commonly used filler fire retardants, as they are more 'greener', more environmentally friendly cleaner, and less energy intensive production process [17-20].

There are mainly two types of flame resistant paper applications. One category of the papers is composed of a combination of inorganic mineral fibers can include asbestos, mineral wool, glass fiber, and sepiolite fibers. The other class of paper with flame-retardant effect is made by adding a variety of flame-retardants in the pulp, or by dip-coating [7]. 
The main purpose of this work is to prepare paper sheets based on unbleached rice straw which cause environmental problem, by adding different inorganic salts with different concentration that work as flame retardants. Then, evaluation the fire extinguishing effectiveness of paper modified with various inorganic salts using a simple bench-scale laboratory apparatus constructed for this purpose. Also, investigate the physical, mechanical and thermal properties of these modified papers sheets.

\section{EXPERIMENTAL}

\subsection{Materials}

Unbleached rice straw soda pulp was used, inorganic salts included, Lithium hydroxide one hydrate $\left(\mathrm{LiOH} .1 \mathrm{H}_{2} \mathrm{O}\right)$ was purchased from (S. d. fine- Chem Ltd. Mumbai-India), magnesium hydroxide ( $\mathrm{Mg}$ $\left.(\mathrm{OH})_{2} \cdot 15 \mathrm{H}_{2} \mathrm{O}\right)$, aluminum sulphate $\left(\mathrm{Al}_{2}\left(\mathrm{SO}_{4}\right)_{3}\right)$ and calcium carbonate $\left(\mathrm{CaCO}_{3}\right)$ were provided by (Sisco Research Laboratories Pvt. Ltd. Bombay-India). These inorganic salts were added to pulp in different concentrations $(5,10,15,20,25$, and $30 \%)(\mathrm{W} / \mathrm{W})$.

\subsection{Methods}

\subsubsection{Preparation of Paper Sheets}

Rice straw pulp is prepared by kraft method [21]. The paper sheets were prepared according to the S.C.A standard, using the model S.C.A sheet former (AB Worentzen and Wettre). In the apparatus a sheet of $165 \mathrm{~mm}$. diameter and $214 \mathrm{~cm}^{2}$ surface area was formed. The weight of oven dry unbleached rice straw pulp used for every sheet was about $3.2 \mathrm{gm}$. The obtained pulp was washed with water till neutrality, filtered and beaten in a valley better for 8 minutes to obtain slurry. Paper sheets were made from this slurry according to TAPPI Standard Method using the sheet former of $A B$ Lorentzen (Stockholm, Sweden). After sheet formation, the paper sheets were pressed for 4 minutes using a hydraulic press, drying of the paper sheets was made with the help of a rotating cylinder or drum at $62.5 \pm 2.5^{\circ} \mathrm{C}$ for 2 hours. The prepared paper sheets were then placed for conditioning at $65 \%$ relative humidity and temperature ranging from 18$20^{\circ} \mathrm{C}$

\section{CHARACTERIZATION}

\subsection{Horizontal Burning Test}

Samples with diminution $\left(10 \times 100 \mathrm{~mm}^{2}\right)$ were exposure to horizontal burning. The flame temperature was $\left(450^{\circ} \mathrm{C} \pm 30^{\circ} \mathrm{C}\right)$, the size of the flame was $(30 \mathrm{~mm}$ $\pm 5 \mathrm{~mm})$ and the diameter of the flame was $(5 \mathrm{~mm} \pm$ $1 \mathrm{~mm}$ ) for time ranging between 0 till complete burning.

\subsection{Paper Testing}

The sheets were tested for tensile strength according to German Standard method by means of a Karl Frank 468 tester (Weinheim-Berkenau) and burst strength according to TAPPI Standard test method 403. A. Mullen (Perkins, Chicopee, MA, USA) was used.

\subsection{Water Absorption (Swelling Character)}

Samples were weighed prior to water treatment and then immersed in water for different times. After removal the prepared paper sheets they were wiped with tissue paper to remove excess water on the surface, and then reweighed, the process was repeated after regular time intervals to find out the amount of water absorbed as a function of time.

Water absorption capacity $(\omega)$ was determined from the relationship.

$$
(\omega)=\frac{\mathrm{W}-\mathrm{W}_{0}}{\mathrm{~W}} \times 100=\ldots . . \%
$$

Where, $W_{0}$ and $W$ are the weights of paper sheet before and after immersion in water respectively. Water retention: ASTM D2402-90.11

\subsection{Infrared Spectra}

IR spectra were carried out using FT-IR Nexus 670, infrared spectrometer, Nicolet (USA) over range 400$4000 \mathrm{~cm}^{-1}$ with resolution of $4 \mathrm{~cm}^{-1}, \mathrm{KBr}$ disk technique was applied at NRC, Egypt.

\subsection{Scanning Electron Microscope}

Samples were subjected to sputter coating of gold ions which act as conducting medium during scanning with Jeol scanning microscope type JXA-840A, Japan.

\subsection{Thermo Gravimetric Analysis}

The thermal properties of treated and untreated samples were carried out using thermal gravimetric analysis (TGA) Perkin Elmer, with rate $10^{\circ} \mathrm{C} \cdot \mathrm{min}^{-1}$, the temperature range from room temperature up to $500^{\circ} \mathrm{C}$ under nitrogen atmosphere. 
Table 1: Relation between Concentrations of Inorganic Salts on the Rate of Combustion

\begin{tabular}{|c|c|c|c|c|c|c|}
\hline \multirow{2}{*}{$\begin{array}{c}\text { Treatment } \\
\text { Material }\end{array}$} & \multicolumn{5}{|c|}{ Concentration \% } \\
\cline { 2 - 7 } & $\mathbf{5 \%}$ & $\mathbf{1 0 \%}$ & $\mathbf{1 5 \%}$ & $\mathbf{2 0 \%}$ & $\mathbf{2 5 \%}$ & $\mathbf{3 0} \%$ \\
\hline \hline $\mathrm{LiOH}$ & 15.3 & 15.33 & 16.08 & 18.61 & 16.44 & 14.96 \\
\hline $\mathrm{Mg}(\mathrm{OH})_{2}$ & 16.14 & 17.75 & 18.43 & 18.71 & 20.08 & 20.35 \\
\hline $\mathrm{Al}_{2}\left(\mathrm{SO}_{4}\right)_{3}$ & 16.5 & 17.1 & 17.84 & 18.7 & 17.15 & 20.1 \\
\hline $\mathrm{CaCO}_{2}$ & 14.08 & 15.31 & 16.74 & & 17.67 \\
\hline Blank & 13.25 & \multicolumn{3}{|c|}{} \\
\hline
\end{tabular}

\section{RESULTS AND DISCUSSIONS}

Packaging materials offer physical protection and produce suitable physicochemical conditions for goods that are necessary for achieving a satisfactory shelf life. The packaging system, based on a proper alternative of the packaging materials artistic with proper gas and water vapor barrier and mechanical properties, prevents product deterioration attributable to physicochemical or biological factors and upholds the overall quality during storage and handling. Furthermore, the using of packaging materials, such as shopping bags, still easily detectable in the environment in many countries. The addition of flame retardant materials (such as inorganic salts) to paper as packaging materials provide them new properties that help it to be competitive materials in packaging applications.

\subsection{Horizontal Burning Test}

The experimental test samples with diminution ' $10 \mathrm{x}$ $100 \mathrm{~mm}^{2}$ ' specimen was used a held at one end in a horizontal position with scripts at every $10 \mathrm{~mm}$. A flame is applied to the free end for 30 seconds or until the flame front reaches the 1" mark, combustion continues and the duration time was measured and recapitulated in Table 1.

From Table 1, it was found that all samples loading with different inorganic salts have better flame retardant than the blank by increasing the loading of salts there are increasing in the time of ignition. It can be noticed that all samples except samples loading with $\mathrm{LiOH}$ which increase by adding up to $20 \%$ then the rate decrease. The best system which have longer time of ignition is the samples loading with $\mathrm{Mg}(\mathrm{OH})_{2}$. This it can explain by the effect of metal oxides resulting from

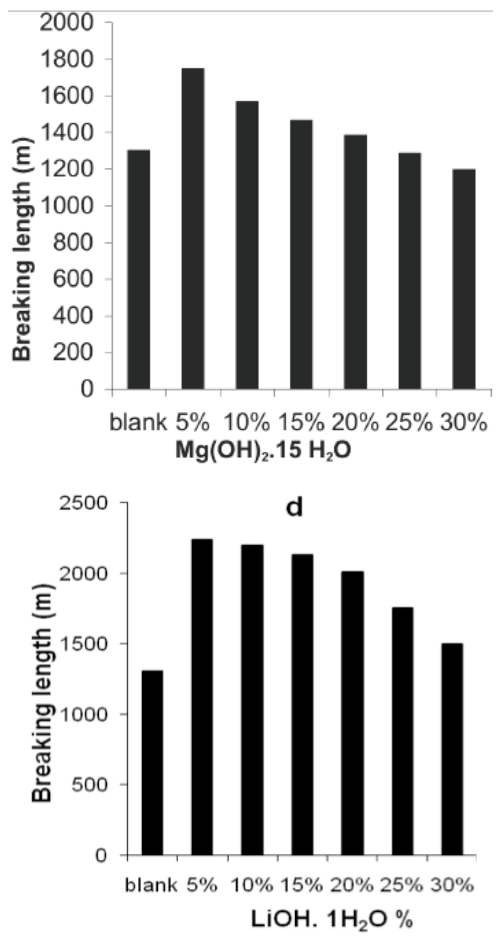

Figure 1: Breaking length of unbleached rice straw soaked with different concentrations of, $\left.(\mathbf{a}) \mathrm{Al}_{2}\left(\mathrm{SO}_{4}\right)_{3} \%,(\mathbf{b}) \mathrm{Mg}_{(\mathrm{OH}}\right)_{2} .15$ $\mathrm{H}_{2} \mathrm{O} \%$ (c) $\mathrm{CaCO}_{3} \%$, (d) $\mathrm{LiOH} .1 \mathrm{H}_{2} \mathrm{O} \%$. 
decomposition of inorganic salts that effectively protects the paper from heat also the release of $\mathrm{H}_{2} \mathrm{O}$ of hydrated hydroxide inhibit ignition processes. Moreover, this phenomenon may be attributed as a result of the combination which shows that the endothermic release of water and carbon dioxide from inorganic salts between $220^{\circ} \mathrm{C}$ and $500^{\circ} \mathrm{C}$ helps diminish heat release so increase the time of ignition; consequently delay firing process.

From the Table 1, it was also distinguished that the blank sample take $13.25 \mathrm{sec}$. to be complete ignition while samples after treatment take more time for ignition and this time increase by increasing concentration of inorganic salts which reach to 20.35 and 20.1 second for samples treated with $\mathrm{Mg}(\mathrm{OH})_{2}$ and $\mathrm{Al}_{2}\left(\mathrm{SO}_{4}\right)_{3}$ respectively. This means that the enhancement in ignition rates may reach to $65 \%$ for the treated paper compare with untreated one.

\subsection{Effect of Addition of Inorganic Salts in Breaking Length}

In many packaging applications, mechanical properties as well as barrier properties are required for good packaging. In general, mechanical properties of paper sheet in a composite structure tend to rely strongly on the substrate or base paper sheet rather than the different additives were added to the paper sheet. The mechanical property frequently measured to characterize paper-based packaging materials is tensile strength. Results in Figure 1 of breaking length for the paper sheets containing different additives concentrations from 5 to $30 \%$ shows that all samples loaded with inorganic salts have higher breaking length than the blank except samples loaded with $\mathrm{Al}_{2}\left(\mathrm{SO}_{4}\right)_{3}$ which have breaking length less than the blank sample. Furthermore, the breaking length decreases with increasing fillers concentrations or more addition of inorganic salts. This decrease in breaking length may be due to the reduction in fiber-to-fiber bonding as a result of the interference of inorganic salts with rice straw fibers.

\subsection{Effect of Addition of Inorganic Salts in Tear Factor}

The tear factor of the unbleached rice straw is higher than that of the different paper sheets loaded
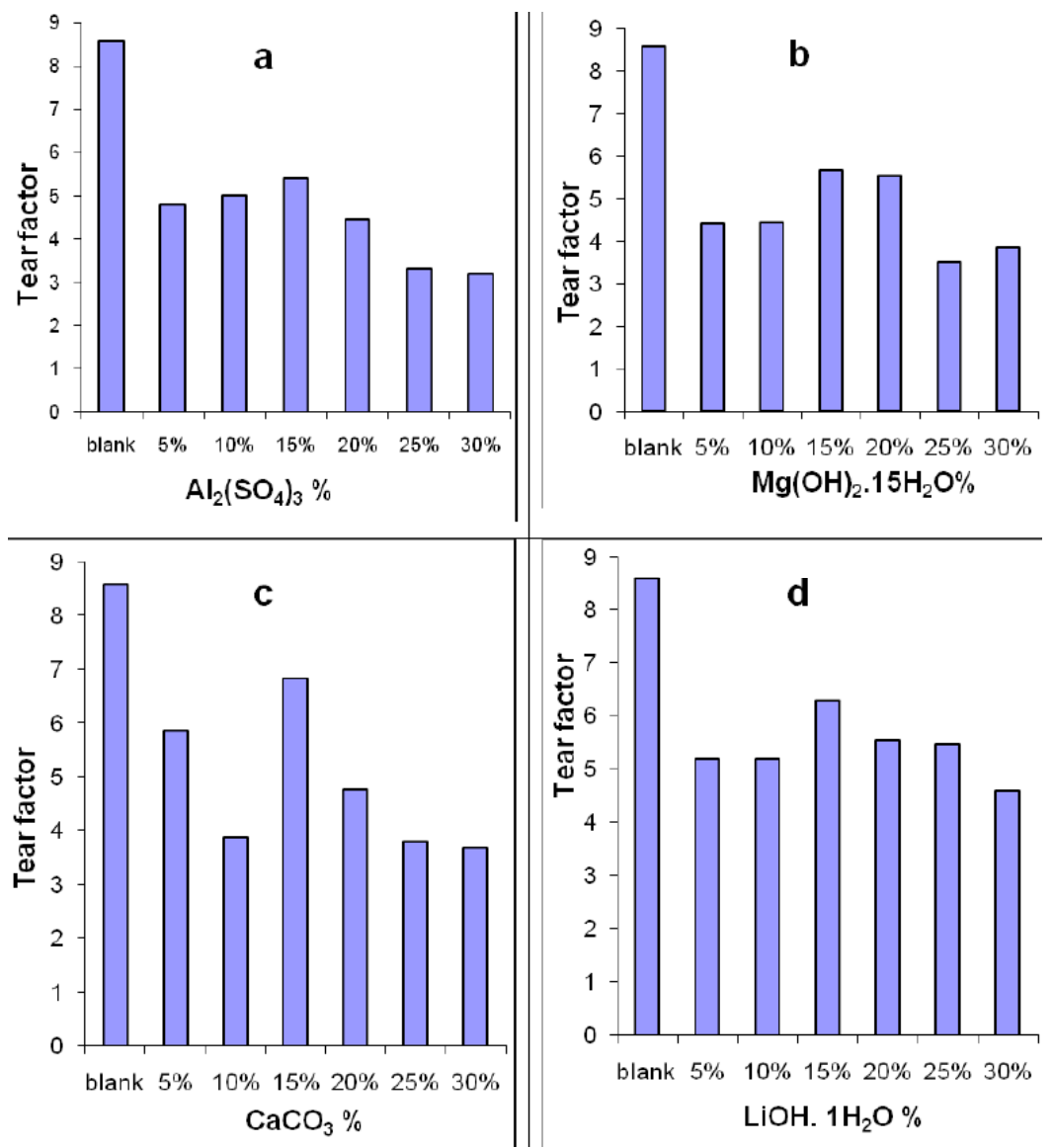

Figure 2: Tear factor of unbleached rice straw soaked with different concentrations of, (a) $\mathrm{Al}_{2}\left(\mathrm{SO}_{4}\right)_{3} \%$, (b) $\mathrm{Mg}(\mathrm{OH})_{2} .15 \mathrm{H}_{2} \mathrm{O}$, (c) $\mathrm{CaCO}_{3} \%$, (d) $\mathrm{LiOH} .1 \mathrm{H}_{2} \mathrm{O} \%$. 
with different inorganic salts additives. The tear factor for paper sheet samples loading with $\left(\mathrm{Al}_{2}\left(\mathrm{SO}_{4}\right)_{3}, \mathrm{Mg}\right.$ $(\mathrm{OH})_{2} .15 \mathrm{H}_{2} \mathrm{O}, \mathrm{CaCO}_{3}$, LiOH. $\left.1 \mathrm{H}_{2} \mathrm{O}\right)$, increased by increasing the concentrations of this additives up to the ratio of $15 \%$ but more addition leads to decreases in the tear facto in all paper sheet for all inorganic salts additives, so $15 \%$ consider the best ratio of this additives as shown in Figure 2.

\subsection{Effect of Addition of Inorganic Salts in Burst Factor}

Figure 3 reveals that the burst factor decrease slightly in case of using $\left(\mathrm{Al}_{2}\left(\mathrm{SO}_{4}\right)_{3}, \mathrm{Mg}(\mathrm{OH})_{2} .15 \mathrm{H}_{2} \mathrm{O}\right.$, $\mathrm{CaCO}_{3}$ ) which appear to decrease with increase the filler concentrations also the $15 \%$ concentration is the best one among all other concentrations. Whereas, by using $\mathrm{LiOH} .1 \mathrm{H}_{2} \mathrm{O}$ with different concentrations the burst factor increases till $15 \%$ and then start to decrease again by increasing the filler.

\subsection{Effect of Addition of Inorganic Salts in Water Absorption}

The water resistance value is the most widely measured parameter of the fiber swell ability in water. Water absorption of pulp is directly proportional to the amount of the disordered region in fibers (amorphous). The used pulp is unbleached and contains lignin, which is considered a highly disordered matter.

On the other hand, the effect of addition of different concentrations of inorganic salts on water absorption of paper sheets is shown in Figures 4(a-d). From Figures, it is noticed that all paper sheets samples loaded with all inorganic salts have water absorption values higher than the blank. Decrease in water resistance due to their hydrophilic character of inorganic salts.

From Figure $\mathbf{4 a}$, the prepared rice straw paper sheet has water absorption lesser than that loaded with $\mathrm{LiOH}$, the rate of absorption was increasing by time and with increasing the lithium hydroxide concentrations from up to $15 \%$ over this percentage the water absorption start to decrease again. This can be attributed to the penetration of $\mathrm{LiOH}$ particles into the surfaces of paper sheet, from observations these particles seem to resist to water by increase the concentration in paper sheet.

According to Figure $\mathbf{4 b}$, the prepared rice straw paper sheet had low absorption rate of water during the 2, 4, 6, 8 and $10 \mathrm{~min}$ at different concentrations of calcium carbonate $\left(\mathrm{CaCO}_{3}\right)$, whereas the absorption rate of water paper sheet loaded with $\mathrm{CaCO}_{3}$ was increasing with increasing the calcium carbonate from 5 to $30 \% \mathrm{CaCO}_{3}$. This result may be ascribed to the high hydrophilic character of the calcium carbonate which leads to more water absorption by paper sheet.

It was noticeable from Figure $\mathbf{4 c}$ that the prepared rice straw paper sheet also had the low water absorption rate during all the time intervals $(2,4,6,8$ and $10 \mathrm{~min}$ ) at different concentrations of magnesium hydroxide $\mathrm{Mg}(\mathrm{OH})_{2}$, although the water absorption rate of water was increasing with increasing the $\mathrm{Mg}(\mathrm{OH})_{2}$ from $(5-30 \%)$. This owing to the increasing the number of hydroxide groups and correspondingly increasing hydrophilic character of the treated paper sheet prepared from unbleached rice straw.

As seen from Figure $\mathbf{4 d}$ for all different concentration of aluminum sulphate $\mathrm{Al}_{2} \quad\left(\mathrm{SO}_{4}\right)_{3}$ at different time the prepared rice straw paper sheet appear low water absorption rate. This similar to the function of using magnesium hydroxide $\mathrm{Mg}\left(\mathrm{OH}_{2}\right)$ as filler to treat the unbleached rice straw paper sheet.

\subsection{Scanning Electron Microscope}

Figure 5 shows the scanning electron microscope of the prepared paper sheet with and without addition of inorganic salts. Figure 5a, showed that the untreated paper sheet without any additives of inorganic salts, while Figure $\mathbf{5 b}$ reveals that the additions of lithium hydroxide by $(10 \%)$ to the unbleached rice straw pulp, the image illustrates the present of lithium hydroxide on the cellulose fibers pores and also coated the cellulose fibers which entrenched between the paper fibers pores and enhance the fire resistance of paper sheet.

From Figure 5c that demonstrates the morphology of the paper sheet which containing $10 \%$ of $\left(\mathrm{Mg}(\mathrm{OH})_{2}\right)$ the image exemplify the present of magnesium hydroxide onto the surface of cellulose fibers and lay between the paper fibers pores and may be decrease the mechanical properties and improve the fire resistance of paper sheet. Furthermore, by using the calcium carbonate and Aluminum sulphate as filler for paper sheet the scanning electron microscope image illustrated that the incorporation of the filler particles between the paper sheet pores as shown in Figure (5d and $\mathbf{e})$ which improved the different properties of paper sheet. 

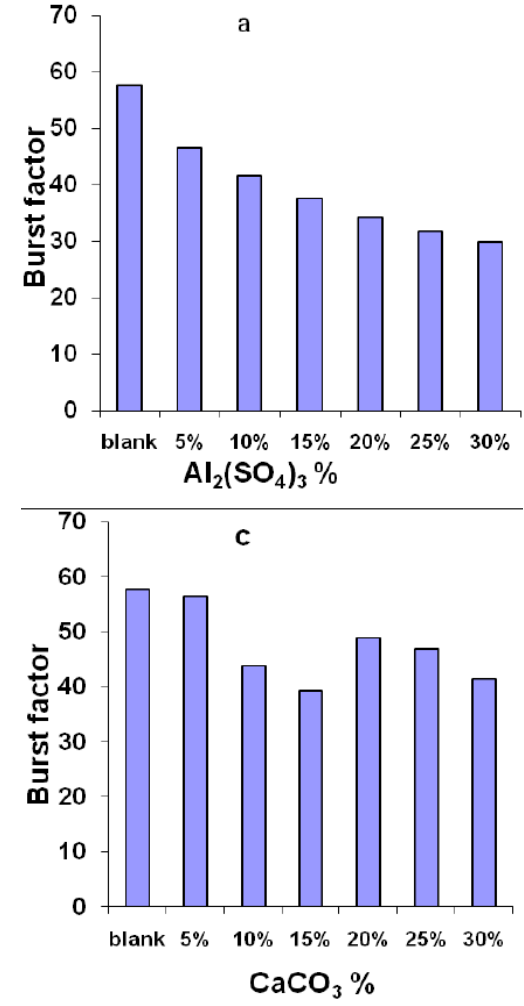

b

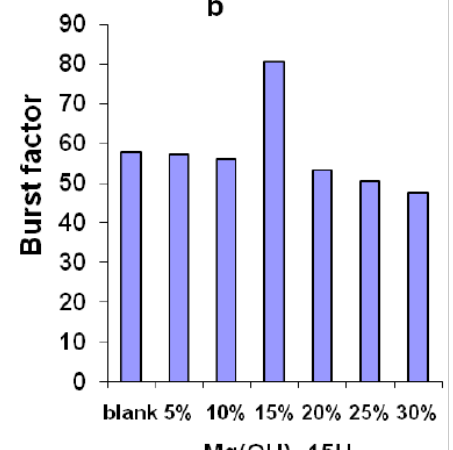
$\mathrm{Mg}(\mathrm{OH})_{2} \cdot 15 \mathrm{H}_{2}$

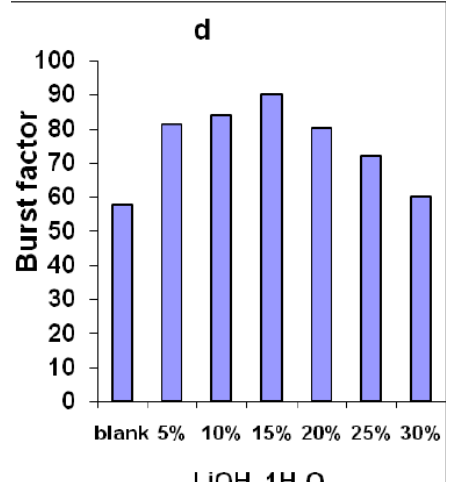

LiOH. $1 \mathrm{H}_{2} \mathrm{O}$

Figure 3: Burst factor of unbleached rice straw soaked with different concentrations of, (a) $\mathrm{Al}_{2}\left(\mathrm{SO}_{4}\right)_{3} \%,(\mathbf{b}) \mathrm{Mg}(\mathrm{OH})_{2} .15 \mathrm{H}_{2} \mathrm{O} \%$, (c) $\mathrm{CaCO}_{3} \%$, (d) $\mathrm{LiOH} .1 \mathrm{H}_{2} \mathrm{O} \%$.

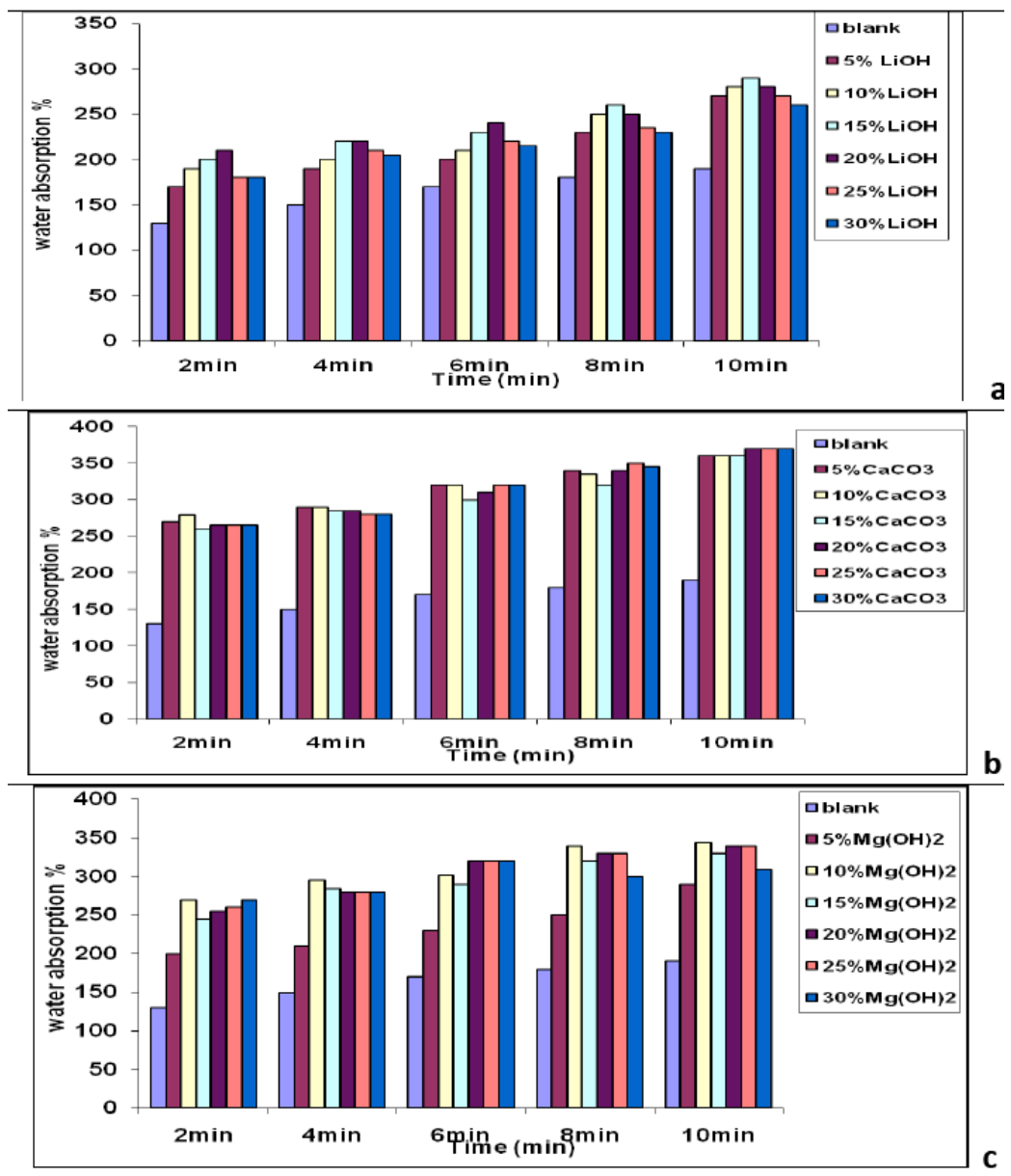




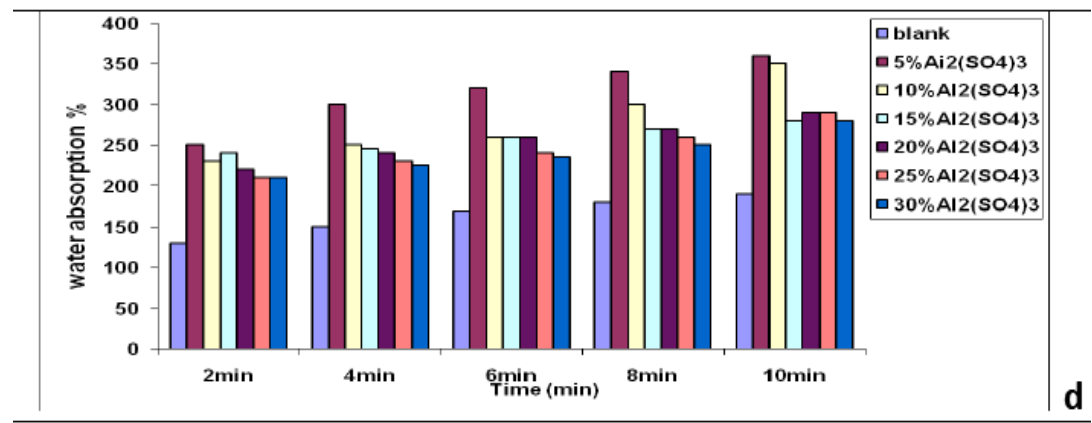

(Figure 4). Continued.

Figure 4: Water absorbance of prepared paper sheet treated with different concentrations of inorganic salts solution, (a)

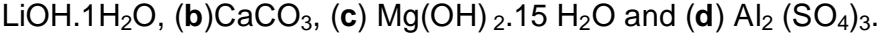

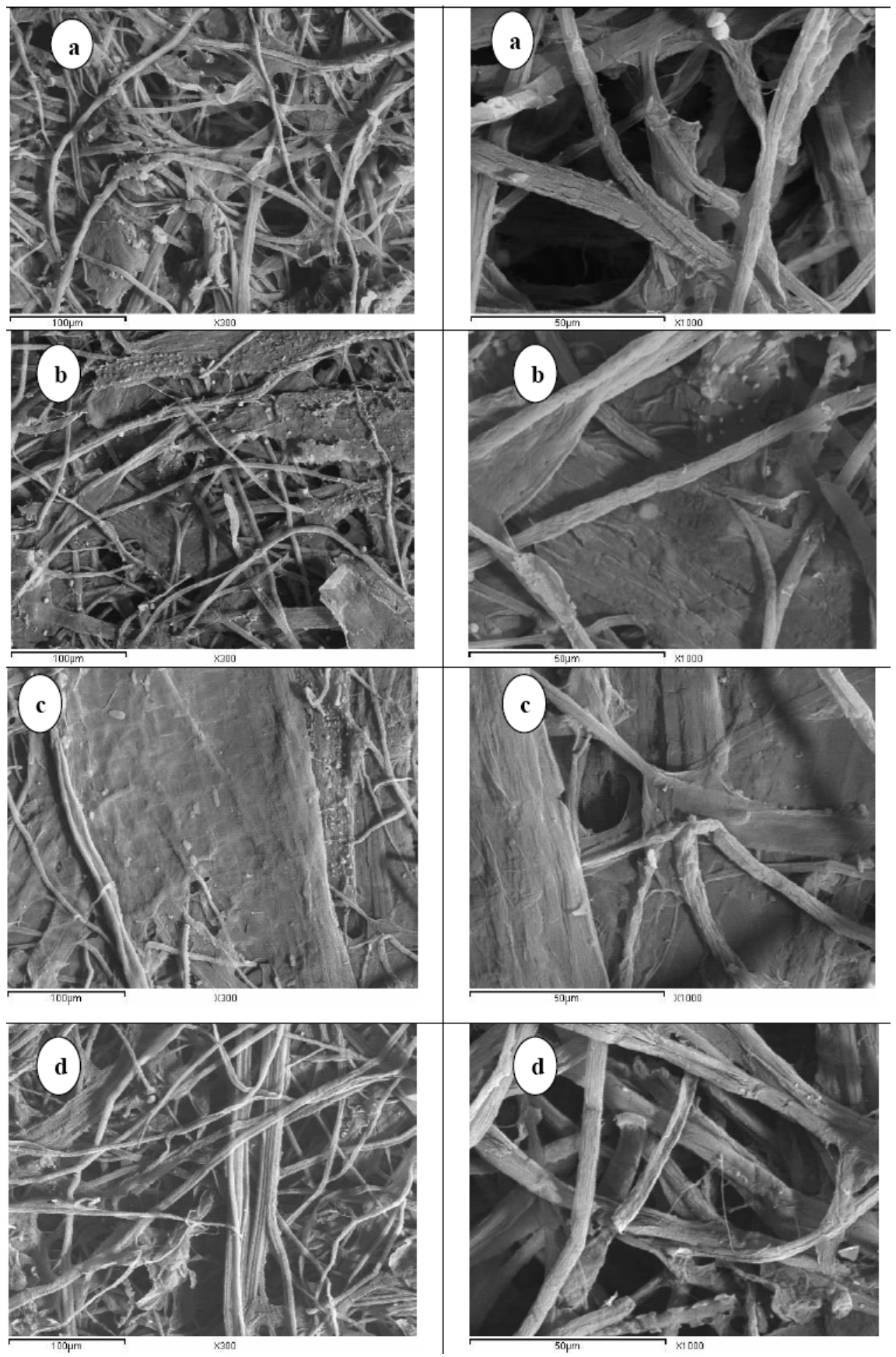


(Figure 5). Continued.

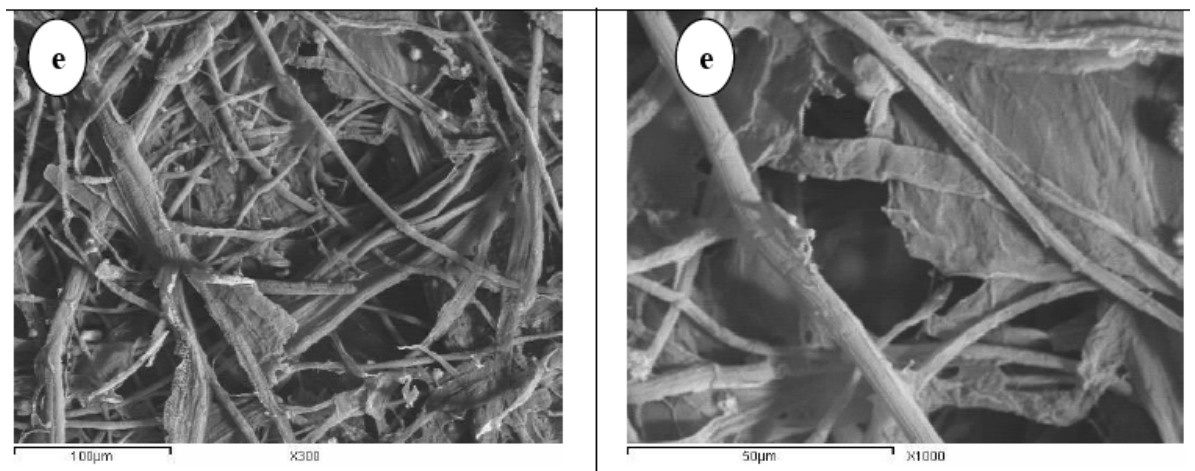

Figure 5: SEM images of (a) blank paper sheet, (b) 10\% $\mathrm{LiOH}_{1} 1 \mathrm{H}_{2} \mathrm{O}$, (c) $10 \% \mathrm{Mg}(\mathrm{OH})_{2} .15 \mathrm{H}_{2} \mathrm{O},(\mathbf{d}) 10 \% \mathrm{Al}\left(\mathrm{SO}_{4}\right),(\mathbf{e}) 10 \%$ $\mathrm{CaCO}_{3}$ (different magnification).

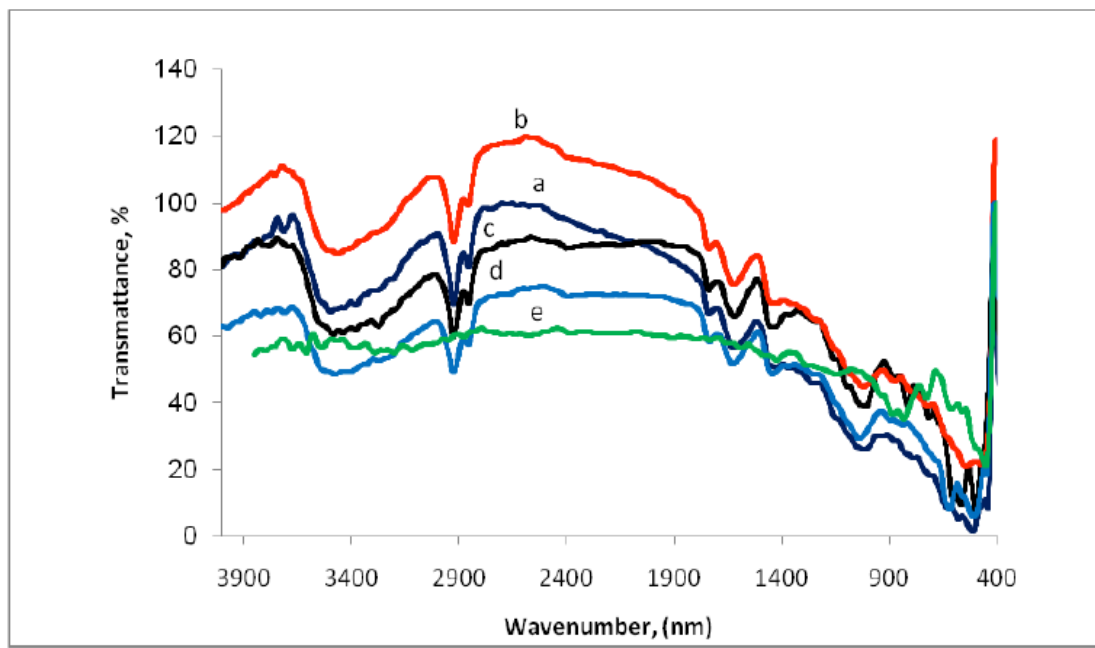

Figure 6: FT-IR spectroscopy of, (a) unbleached rice straw, (b) $5 \% \mathrm{Al}(\mathrm{OH})_{2}$, (c) $5 \% \mathrm{LiOH}^{1} \mathrm{H}_{2} \mathrm{O},(\mathrm{d}) 5 \% \mathrm{CaCO}_{3},(\mathrm{e}) 5 \%$ $\mathrm{Mg}(\mathrm{OH})_{2 .} 15 \mathrm{H}_{2} \mathrm{O}$.

\subsection{FT-IR Spectroscopy of the Prepared Paper Sheet}

To confirm the incorporation of inorganic materials on the cellulosic raw materials (rice straw) sheets we recorded the FTIR spectra of the paper sheet containing different inorganic materials in the diffuse reflectance mode. FTIR spectroscopic evidence confirmed that the characteristic broad band for $\mathrm{O}-\mathrm{H}$ group of cellulosic materials appears around $3,500 \mathrm{~cm}^{-}$ ${ }^{1}$ and a band around 2,940 and $2850 \mathrm{~cm}^{-1}$ because of $\mathrm{C}-\mathrm{H}$ presented in $\mathrm{CH}_{2} \mathrm{OH}$ group of cellulosic rice straw. On the other hand, the bands of all different sheets containing different inorganic materials are matched as shown in Figure 6.

\subsection{Thermal Analysis}

Thermal stability of the prepared paper sheet and the treated paper sheet was carried out under $\mathrm{N}_{2}$ and demonstrates that the TGA measurements of blank paper sheet as well as the paper sheet with different inorganic salts concentrations. At the same concentration $(5 \%)$ of different fillers $\left(\mathrm{LiOH}, \mathrm{Al}(\mathrm{OH})_{2}\right.$, $\mathrm{CaCO}_{3}$ and $\left.\mathrm{Mg}(\mathrm{OH})_{2}\right)$, the weight loss between 25 and $380^{\circ} \mathrm{C}$ is around $80 \%$ and probably the same in all samples and matched with the blank paper sheet. although, the weight lose between $380^{\circ} \mathrm{C}$ to $800^{\circ} \mathrm{C}$ is attributed to the loss of the fillers (inorganic salts) which added to the unbleached race straw pulp and corresponding to around $20 \%$ weight losses.

From the Figure 7, it shown that the paper sheet containing $5 \% \mathrm{Mg}(\mathrm{OH})_{2}$ is more thermal stable compare to the blank paper sheet in the rang from $380^{\circ} \mathrm{C}$ to $800^{\circ} \mathrm{C}$ whereas the other paper sheet containing different fillers (inorganic salts) were more thermal stable in the following sequence $\left(\mathrm{CaCO}_{3}>\mathrm{Al}(\mathrm{OH})_{2}>\mathrm{LiOH}>\right.$ blank sheet $)$ at the same temperature rang $\left(380^{\circ} \mathrm{C}\right.$ to $800^{\circ} \mathrm{C}$ ) as shown in Figure 7. 


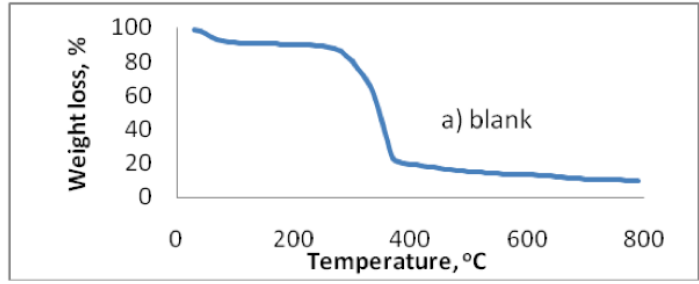

a

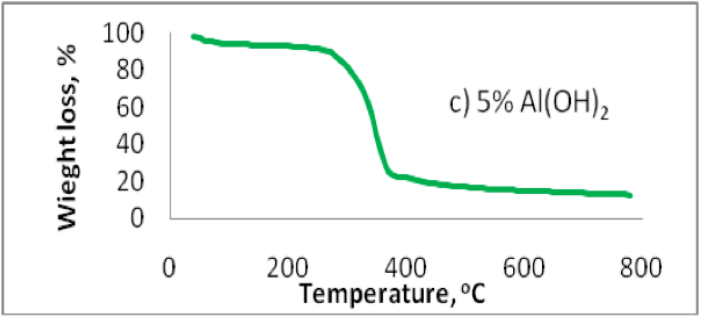

b

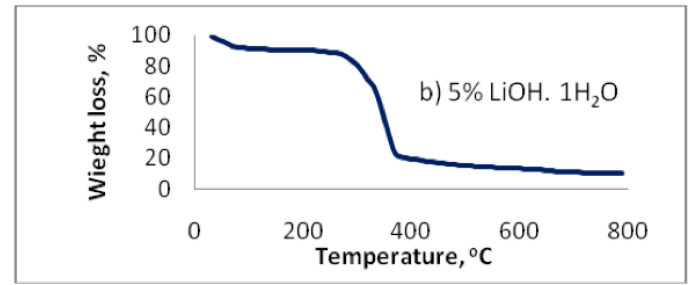

b

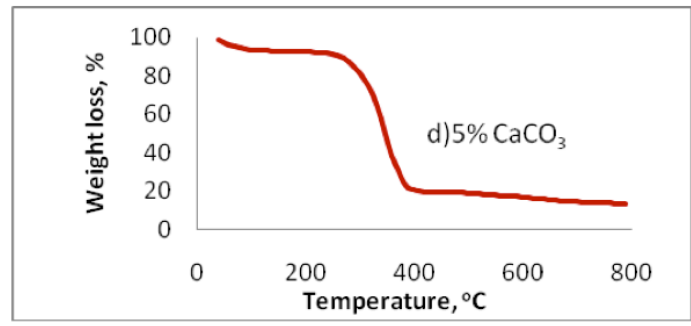

C

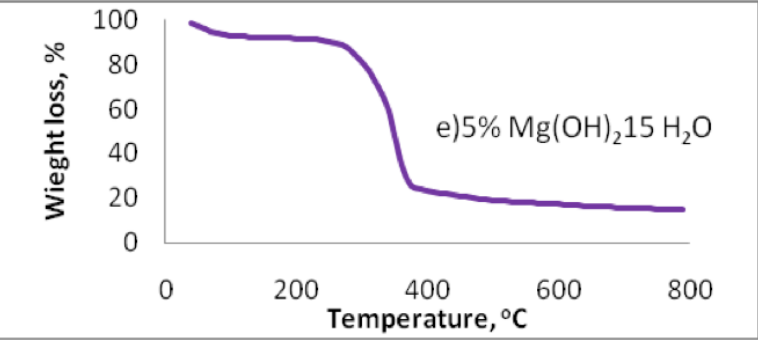

e

Figure 7: TGA thermograms of, (a) blank paper, (b) $5 \% \mathrm{LiOH} .1 \mathrm{H}_{2} \mathrm{O}$, (c) $5 \% \mathrm{Al}_{2}\left(\mathrm{SO}_{4}\right)_{3},\left(\right.$ d) $5 \% \mathrm{CaCO}_{3},(\mathbf{e}) 5 \% \mathrm{Mg}(\mathrm{OH})_{2} .15 \mathrm{H}_{2} \mathrm{O}$.

\section{CONCLUSION}

The study succeeded to prepare paper sheets loaded with different inorganic salts, which have high flame retardancy in comparison with blank one reached to $65 \%$, with keeping the other physical and mechanical properties without deterioration. In addition, the increasing some properties such as tensile, tear factor and water absorption were also observed. Delaying firing process will help in protecting the materials from burning, saving many of economic effect. So the prepared paper sheet can be used for different industrial applications especially in packaging applications.

\section{REFERENCES}

[1] Youssef AM, El-Samahy M, Abdel Rehim M. Preparation of conductive paper composites based on natural cellulosic fibers for packaging applications. Carbohydrate Polymers 2012; 89: 1027-32.

http://dx.doi.org/10.1016/j.carbpol.2012.03.044

[2] Youssef AM, El-Samahy MA, El-Sakhawy M, Kamel S. Structural and electrical properties of paper-polyaniline composite. Carbohydrate Polymers 2012; 90: 1003-7. http://dx.doi.org/10.1016/i.carbpol.2012.06.034

[3] Nassar MA, Youssef AM. Mechanical and antibacterial properties of recycled carton paper coated by $\mathrm{PS} / \mathrm{Ag}$ nanocomposites for packaging. Carbohydrate Polymers 2012; 89: 269-274. http://dx.doi.org/10.1016/j.carbpol.2012.03.007

[4] Youssef AM, Kamel S, El-Samahy MA. Morphological and antibacterial properties of modified paper by PS nanocomposites for packaging applications. Carbohydrate Polymers 2014; 98: 1166-72. http://dx.doi.org/10.1016/j.carbpol.2013.06.059

[5] Guo X. Production of flame-retardant paper. Paper and Paper Making 2006; 16: 20-3.

[6] Yeh R Y, Yang YT, Perng Y S. Preparation of novel nonhalogen flame-retardant papers. Taiwan J Sci 2011; 26: 879.

[7] Wang S, Huang J, Chen F. Study on Mg-Al hydrotalcites in flame- retardant paper preparation. Bio Resources 2012; 7: 997-1007.

[8] Billa E, Pastou A, Monties B, Romero J, Koukios E.G. Multivariate chemometric analysis of the fluorescence spectra of eucalyptus wood. Ind Crop Prod 2000; 11: 187-96. http://dx.doi.org/10.1016/S0926-6690(99)00062-X

[9] Bertaud F, Holmbom, B. Chemical composition of earlywood and latewood in Norway spruce heartwood, sapwood and transition zone wood. Wood Sci Technol 2004; 38: 245-56. http://dx.doi.org/10.1007/s00226-004-0241-9

[10] Conrad MPC, Smith GD, Fernlund G. Fracture of solid wood: A review of structure and properties at different length scales. Wood Fiber Sci 2003; 35: 570-84.

[11] Sefain MZ, Nada AMA. Thermal behavior of paper sheets strength. Thermochimica Acta 1984; 78: 211-8. http://dx.doi.org/10.1016/0040-6031(84)87146-4

[12] Odlyha M, Seeley $N$, Wettasinghe CS. Applications of differential scanning calorimetry and dielectric thermal 
analysis to the study of paper deterioration. Thermochimica Acta 1990; 166: 1-16.

http://dx.doi.org/10.1016/0040-6031(90)80165-U

[13] Yang F, Chen KF, Yang RD, You P. Chen Q.F. Manufacture of heat resistant interleaving paper for sheet metal. China Pulp Pap 2007; 26: 11-3.

[14] Yang RD, Liao XS, Yang F, Chen KF. Research and heatresistant paper used for stainless steel. Paper and Paper Making 2008; 27: 33-5.

[15] Covaci A, Harrad S, Abdallah M, et al. Novel brominated flame retardants: A review of their analysis, environmental fate and behavior. Environment Int 2011; 37: 532-56. http://dx.doi.org/10.1016/i.envint.2010.11.007

[16] Braun U, Balabanovich AI, Schartel B, Knoll U, Artner, J, Ciesielski M. Influence of the oxidation state of phosphorus on the decomposition and fire behaviour of flame-retarded epoxy resin composites. Polymer 2006; 47: 8495-508. http://dx.doi.org/10.1016/j.polymer.2006.10.022

[17] Hamdani S, Longuet C, Lopez-Cuesta JM, Ganachaud F. Calcium and aluminium-based fillers as flame-retardant additives in silicone matrices. I. Blend preparation and thermal properties. Polymer Degradation and Stability 2010; 5: 1911-9.

http://dx.doi.org/10.1016/i.polymdegradstab.2010.04.013

[18] Criado JM, Ortega A. A study of the influence of particle size on the thermal decomposition of calcium carbonate by means of constant rate thermal analysis. Thermochimica Acta 1992; 195:163-7.

http://dx.doi.org/10.1016/0040-6031(92)80059-6

[19] Hollingbery LA, Hull TR. The thermal decomposition of huntite and hydromagnesite, a review. Thermochimica Acta 2010; 509: 1-11.

http://dx.doi.org/10.1016/j.tca.2010.06.012

[20] Hull TR, Witkowski A, Hollingbery LA. Fire retardant action of mineral fillers, Polymer Degradation and Stability 2012; 96: 1462-9.

http://dx.doi.org/10.1016/j.polymdegradstab.2011.05.006

[21] Ziaie-Shirkolaee Y. Comparative study on hydrogen peroxide bleaching of soda-organosolv and Kraft rice straw pulps. Indian J Chem Technol 2009; 16: 181-7. 